\title{
Yes, nós temos Pasteur
}

\section{Yes, we have Pasteur}

\author{
André Felipe Cândido da Silva \\ Doutorando do Programa de Pós-graduação em Histórias das Ciências \\ e da Saúde/Casa de Oswaldo Cruz/Fundação Oswaldo Cruz \\ Rua Cardeal Dom Sebastião Leme, 125/s402 \\ 20240-012 - Rio de Janeiro - RJ - Brasil \\ andrfe@hotmail.com
}

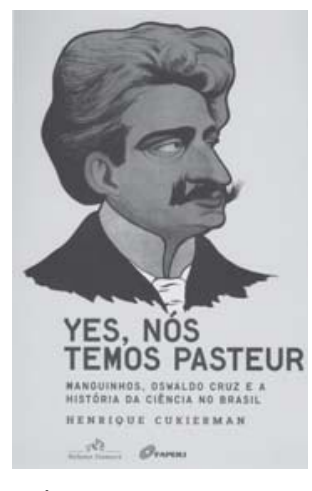

Cukierman, Henrique. Yés, nós temos Pasteur: Manguinhos, Oswaldo Cruz e a história da ciência no Brasil. Rio de Janeiro: Relume-Dumará; Faperj, 2007. 440p.
$\mathrm{E}$ m "Marginália", canção da qual deriva a paródia que dá título à obra de Henrique Cukierman e cujos versos vêm estampados em sua epígrafe, Gilberto Gil e Torquato Neto, afinados com o diapasão do tropicalismo do final dos anos 1960, retratam uma visão tragicômica e carnavalizada da nacionalidade. Entre os versos irônicos e a paródia sarcástica, Gil e Torquato mesclaram referências do tradicional e do moderno com o propósito de explorar as ambiguidades e contradições constitutivas do "ser e estar brasileiro"; positividades e negatividades que não resultam em síntese, mas sim compõem "antagonismos em equilíbrio". Através da 'geleia geral' que borrou as fronteiras entre vanguardismo e tradição, erudito e popular, nacional e universal, os tropicalistas defenderam um projeto intelectual e estético no qual buscaram repensar o lugar da cultura nacional brasileira diante da estrangeira, identificada com a modernidade de matiz universalizante. Inspirados pela cultura pop nacional e internacional e pelas correntes de vanguarda, os tropicalistas propuseram uma renovação da música brasileira, a qual consideravam por demais 'engessada' pela postura tradicional e nacionalista defendida por certos segmentos do universo cultural. Foram buscar em Oswald Andrade e seu manifesto antropofágico as referências para seguir em frente na tarefa de incorporar e digerir, sem constrangimentos, os elementos culturais exógenos, entremesclá-los a uma cultura nacional complexa e heterogênea, constituindo daí um produto híbrido.

Se os impasses e tensões dos artistas dedicados a 'inventar o Brasil' nos anos 1960-1970 refletiram as circunstâncias históricas daquele momento, nem por isso foram dessemelhantes aos que acompanharam a ação de nossos intelectuais em outros contextos. A condição de "desterrados em sua própria terra" foi, segundo Sérgio Buarque de Holanda, constitutiva daqueles que se propuseram a pensar o Brasil e seu lugar no mundo municiados de referenciais exógenos, mas, ao mesmo tempo, dirigindo-se a uma realidade da qual faziam parte e a qual se destinaram a transformar. Resultaram daí tensões e ambiguidades que não estiveram ausentes do horizonte dos que se dedicaram a praticar ciência no Brasil no alvorecer do século XX. São elas que dão o tom da narrativa atraente e bem-humorada de Henrique Cukierman, que revisita o "mito de fundação da tecnociência brasileira": a saga 
de Oswaldo Cruz e seus companheiros em prol da implantação da atividade científica em território pátrio.

Por meio da ciência, ingrediente que é a "pedra de toque da modernidade" (Marques, 2007, p.415), a ação de Oswaldo Cruz é identificada, por Cukierman, como a tentativa de fundação de um novo país que, uma vez despojado das peias do passado colonial, encontrase pronto para integrar o concerto das nações civilizadas. Para tanto, ele deve combater "de varíola a valores, ratos a raízes coloniais, mosquitos a mentalidades burocráticas" (p.12) e demonstrar que, muito embora informados pelos cânones e parâmetros de validação do conhecimento científico sacramentados pelos convencionados 'centros', não somos seus meros imitadores. Para o autor, a viabilização da atividade científica por Oswaldo Cruz demandou a superação da herança ibérica, "construída à base de pessoalidade, afeto, vínculos familiares, improvisação e obediência" e a instauração de uma nova ética, marcada pelo rigor e objetivismo (p.12). Só assim teria sido possível deitar raízes em terras brasílicas a ciência moderna, 'desembarcada', pretensamente neutra e universal, europeia e europeizante, vista como luminar do progresso e inscrita numa realidade considerada subalterna pelos centros de civilização. O impasse de Oswaldo Cruz e seus contemporâneos reside nessa tensão entre a aspiração de reconhecer "a existência de uma ciência do 'centro', a única capaz de legitimar seus esforços ... e a aspiração a relativizar a sua importância" (Löwy, 2006). Ambiguidades e contradições constrangem a ação desses sujeitos que estão num "ir e vir entre a cidade e o campo, entre futuro e passado, entre Paris e Portugal, entre a Nova e a Velha metrópole" (p.146).

Com o propósito de mapear os esforços de Oswaldo Cruz em prol da viabilização do projeto institucional de Manguinhos, empreendimento que se sobrepõe à própria construção do Estado brasileiro republicano, Cukierman busca inspiração teórica em Bruno Latour. Assim, revisita eventos bem conhecidos da historiografia brasileira, no que se refere à institucionalização das ciências, adentrando o laboratório pela porta dos fundos e surpreendendo Oswaldo Cruz e nossos cientistas em sua prática cotidiana de arregimentação de interesses e estabilização de fatos científicos, antes que as 'caixas-pretas' se encontrem cerradas. Na interpretação de Cukierman, na tentativa de radicar esta "ciência desembarcada" e torná-la de validade universal - portanto desadjetivada -, Oswaldo Cruz atrela seu projeto institucional aos interesses da nação brasileira. A campanha contra a febre amarela e a complexa "máquina de sanear" lhe possibilita articular as redes de ciência e saúde pública, ensejando a 'metamorfose' do acanhado casinhoto de Manguinhos em imponente conjunto arquitetônico de estilo mourisco. Ali busca o cientista criar uma "ilha de novos valores", opostos aos vícios e corruptelas de uma sociedade recém-saída da escravidão e na qual se deve observar o rigor dos procedimentos da medicina experimental, identificados com a vanguarda da ciência internacional.

Cukierman analisa como Oswaldo Cruz busca construir consensos a fim de fazer valer sua estratégia de campanha contra a febre amarela, o que lhe permitiu pôr em funcionamento sua "máquina de sanear". Esta contou com o apoio do aparato estatal, o qual garantiu o esquadrinhamento do espaço urbano. A febre amarela ganhou visibilidade a partir não só do laboratório, como também das estatísticas que apresentavam, com a "eloquência dos números", a eficiência da máquina saneadora, vista pelo autor como símbolo da missão 
civilizatória esposada pelas elites republicanas. Cukierman analisa Oswaldo Cruz e sua reforma sanitária tal como Latour (1988) fez com Pasteur e a 'pasteurização da França', matizando porém o contexto brasileiro com suas especificidades: aqui a rede de ciência e saúde pública teria sido urdida, diferentemente da França, através da "figura hiper-amplificada" de Oswaldo Cruz, a qual teria dispensado "a mobilização de coletivos" (p.114).

No esforço de levar a contento a tarefa de sanear a capital, Oswaldo Cruz teve de suplantar, segundo Cukierman, não só as resistências da medicina rotulada de 'clínica', como também as rebeliões das classes populares. Sensibilizadas pelas britadeiras e ordens de despejo de Pereira Passos, elas protagonizaram, em 1904, a Revolta da Vacina, episódio analisado em minúcias pelo autor. A revisão criteriosa da historiografia concernente ao assunto bem que poderia ter estado presente em igual medida nos outros capítulos, em que muitas vezes ele reitera estilosamente interpretações já apresentadas por outros atores, sem, contudo, explicitar o diálogo. Cukierman propõe uma análise da Revolta a partir da própria vacina - para ele uma deficiência dos outros trabalhos que abordam o tema -, que deve ser vista na perspectiva de um movimento bem mais amplo de resistência ao imunizante e e deve ser qualificada, não como resistência, mas como ação consciente de atores, encarados a partir de seus referenciais próprios de racionalidade e de sua historicidade. $\mathrm{O}$ autor propõe então a recuperação da fala dos protagonistas silenciados da revolta, como a figura do Prata Preta, numa reedição da proposta da 'história vista de baixo' ou 'história dos vencidos'. Cukierman não leva a contento nem esta nem outras propostas analíticas apresentadas. Contribui bastante, ao ressaltar a riqueza e complexidade do episódio, mas carece de conclusões mais consistentes, o que justifica com a defesa de uma "narrativa das multiplicidades", que abrange todas as explicações e interpretações reconhecendo, ao mesmo tempo, seu caráter limitado. Em suas palavras, a Revolta da Vacina caracteriza-se como "um conjunto fracamente coesionado, submetido a circunstâncias em permanentes realinhamentos e reconfigurações" (p.301).

Sem "confundir a força de Oswaldo com aquela que lhe é atribuída" (p.149), o autor destaca sua mobilidade entre "múltiplos espaços locais e internacionais" como fator que teria possibilitado a articulação estratégica dessas duas dimensões complementares e fundamentais à ciência daquele tempo. É nesse registro que aborda a participação brasileira na Exposição de Higiene de Berlim, em 1907, acompanhando as agruras e os impasses dos preparativos que envolveram Oswaldo Cruz e Henrique da Rocha Lima, "vertente germânica da ciência internacional" (p.316). Ele o faz através de instigante leitura da correspondência de Oswaldo Cruz com o principal propagandista de Manguinhos entre os alemães. A "estampilha do Velho Mundo" obtida em Berlim garante o estatuto legal de Manguinhos e a decolagem de seu projeto institucional. Cukierman recorre a Sérgio Buarque para assinalar como os vínculos de solidariedade e a lógica patriarcal, intrínsecos à nossa tradição cultural de matriz ibérica, configuram o perfil da ciência institucionalizada no Brasil, onde os limites não bem arbitrados entre o público e o privado conformam as relações do aparato científico com o Estado.

Identificados como autênticos representantes da ciência internacional, os cientistas de Manguinhos lançaram os olhos para o interior em busca da identidade do país, colocandose, de acordo com Cukierman, como colonizadores-colonizados. No encalço do processo 
de expansão simbólica e material da nação brasileira, eles embrenharam-se pelos sertões e revelaram à 'civilização do litoral' um país bastante diferente daquele evocado pelas representações românticas. Cukierman analisa esse processo de 'invenção do Brasil' a partir da mais conhecida das expedições científicas do Instituto Oswaldo Cruz, a de Arthur Neiva e Belisário Penna pelo interior do Brasil, em 1912. Faz uma leitura exegética do famoso relatório por eles escrito e se baseia nos estudos pós-coloniais de Sandra Harding e Mary Louise Pratt para demonstrar como sua postura e discurso são marcados por constantes oscilação e deslocamento entre a posição de colonizadores - representantes dessa 'civilização litorânea' que se lança aos interiores, buscando inseri-los na via do progresso - e a de colonizados - constituídos a partir de referenciais gestados em realidades exógenas e que, na procura pelo outro, pelo nativo, estão à procura de si mesmos (p.368).

$\mathrm{Na}$ 'zona de contato' em que se confrontaram com os sertanejos "expulsos da história" e destituídos de qualquer sentimento de nacionalidade, os "cientistas expedicionários" colocaram-se entre a condenação e a repulsa, a redenção e a admiração. Pretendiam construir a figura do autêntico brasileiro, mas não se despiram da arrogância de seu "olhar imperial". A distância histórica e geográfica do litoral e do sertão são aproximados nesse espaço de negociação e tradução, cujos termos não são simétricos, uma vez que uma parte se coloca como representante de um saber universal e superior ao 'local', ao qual cabe ser subjugado. Segundo Cukierman, Neiva e Penna não só representam essa civilização do litoral e a ciência de pretensão universal e neutra, como também atuam como 'pontas de lança' do capitalismo. Devido ao caráter da expedição, financiada pela Inspetoria de Obras Contra as Secas, ela é vista como um empreendimento a serviço do capitalismo edificado nas cabeças 'urbanas' do país em expansão pelos interiores. Crentes irrestritos na capacidade da ciência em redimir essas populações sertanejas, tais "cientistas expedicionários" buscaram "afiançar os trópicos" como locais propícios ao florescimento de uma civilização, desde que seguida a via segura do progresso científico. Pretenderam inventar um novo Brasil, no qual caberia a Manguinhos e à ciência assegurar a salvaguarda desse povo abandonado à própria sorte, infestado de parasitas e sem nenhuma referência do que fosse o sentimento de pertencimento à nação.

Ao revisitar essa saga de invenção de um novo Brasil via cultivo da atividade científica e busca de plena integração à modernidade, Cukierman elide as dualidades que fundam a imagem autoconstruída pelas ciências e que, ao fim e ao cabo, radicam a própria modernidade. Os dualismos local/universal, contexto/conteúdo, natureza/cultura e principalmente - ciência/sociedade ou ciência/política são sinalizados como representações constituídas no ato de 'fabricação' dos fatos científicos, em que o mundo ruidoso dos interesses e das controvérsias cede lugar ao universo asséptico das certezas objetivas e neutras. Do mesmo modo, o modelo de dependência cristalizado no conceito de centro/periferia é desmobilizado em prol de uma concepção segundo a qual todas as formas de conhecimento e cultura são localmente situadas.

Por outro lado, Cukierman orienta sua narrativa a partir de outros dualismos, como moderno e atrasado, velha e nova metrópole, tradição e modernidade, erudito e popular, litoral e sertão, público e privado, colonizador e colonizado, embora tais categorias nem sempre apareçam como pares de opostos, mas sim como instâncias que ora se confundem, 
ora se complementam. Na "maneira construtivista" de contar histórias, como denomina o próprio autor, alguns aspectos não são explorados em toda a sua complexidade. Identificar Oswaldo Cruz à "escola francesa" e Rocha Lima à alemã consiste num certo reducionismo que obscurece o ecletismo que marcou não só Manguinhos, como a tradição científica brasileira, no que se refere à incorporação 'antropofágica' de tradições das mais diversas origens, inclusive inglesa e norte-americana, sem filiação unívoca. O autor incorre no mesmo simplismo quando identifica a ação "expedicionária" de Neiva e Penna à expansão capitalista, deixando à sombra uma série de motivações e consequências relacionadas ao percurso pelo interior do Brasil. Ademais, calcado no modelo de ator-rede de Latour, o qual rejeita dentro do "programa forte" defendido por David Bloor (1976) o princípio da causalidade, Cukierman faz uma leitura da atuação de Oswaldo Cruz na identificação da peste bubônica em Santos como se o Instituto Soroterápico fosse dali uma consequência inelutável ou um ponto de chegada lógico e necessário.

No que concerne às teorias científicas propriamente ditas, o autor assume a bacteriologia e pasteurianismo como bases conceituais a partir das quais se teria constituído a teoria culicidiana, enquanto historiografia recente vem demonstrando que a emergência da medicina tropical, vazada no modelo conceitual do parasito-vetor, operou descontinuidades em relação àquele campo de saber (Benchimol, 1999; Benchimol, Sá, 2005; Caponi, 2003; Kropf, 2009; Worboys, 1993, 1996).

Cumpre ressaltar, no entanto, que o autor mostra cautela na aplicação de modelos analíticos, procurando matizar o caso brasileiro com proposições mobilizadas para se pensar a constituição das redes sociotécnicas em geral em países de grande desenvolvimento científico. Com olhar arguto, não cai nas malhas dos discursos de seus personagens; antes, os descontrói, para demonstrar a existência de uma outra história, oposta àquela "que estabelece verdades e ilusões como absolutos irreversíveis. Costumam alardear vitórias, consagrar sucessos e desprezar perdedores" (p.145). Sem se entregar às seduções do mito, tanto o "da ciência e seus produtos tecnológicos" quanto o de Oswaldo Cruz, Cukierman logra a contento atrair o leitor do início ao fim de sua narrativa, sem cair no enfado do rigorismo acadêmico, e mostra "com quantas precariedades se faz uma certeza, com quanto medo blasona o herói sua coragem, com quantas paixões subterrâneas se faz a ciência" (p.57).

\section{REFERÊNCIAS}

BENCHIMOL, Jaime Larry.

Dos micróbios aos mosquitos: febre amarela e a revolução pasteuriana no Brasil. Rio de Janeiro: Fiocruz; UFRJ. 1999.

BENCHIMOL, Jaime Larry; SÁ, Magali Romero. Insetos, humanos e doenças: Adolpho Lutz e a medicina tropical. In: Benchimol, Jaime; Larry; Sá, Magali Romero (Org.). Adolpho Lutz: obra completa. v.2, livro 1. Rio de Janeiro: Fiocruz. p. $43-457.2005$.

BLOOR, David.

Knowledge and social imagery. Londres:

Routledge \& Kegan Paul. 1976.
CAPONI, Sandra.

Coordenadas epistemológicas de la medicina tropical. História, Ciências, Saúde - Manguinhos, Rio de Janeiro, v.10, n.1, p.113-149. 2003.

KROPF, Simone P.

Doença de Chagas, doença do Brasil: ciência, saúde e nação (1909-1962). Rio de Janeiro: Editora Fiocruz. 2009.

LATOUR, B.

The pasteurization of France. Massachusetts: Harvard University Press. 1988. 
LÖWY, Ilana.

Virus, mosquitos e modernidade: a febre amarela no Brasil entre ciência e política. Rio de Janeiro: Editora Fiocruz. 2006.

MARQUES, Ivan da Costa.

Posfácio. In: Cukierman, Henrique. Yes, nós temos Pasteur: Manguinhos, Oswaldo Cruz e a história da ciência no Brasil. Rio de Janeiro: Relume Dumará; Faperj, p.411-427. 2007.

WORBOYS, Michael.

Germs, malaria and the invention of mansonian tropical diseases. In: Arnold, David (Ed.). Warm climates and Western medicine: the emergence of tropical medicine, 1500-1900. Amsterdam: Rodopi. p.181-207. 1996.

WORBOYS, Michael.

Tropical diseases. In: Bynum, William F.; Porter, Roy (Ed.). Companion encyclopaedia of the history of medicine. London: Routledge. p.512-536. 1993.

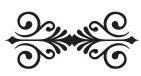

